\title{
Effects of grassland burning on reproductive success of globally threatened Strange-tailed Tyrants Alectrurus risora
}

\author{
ALEJANDRO G. DI GIACOMO, ADRIAN S. DI GIACOMO and JUAN C. \\ REBOREDA
}

\section{Summary}

The north-east of Argentina contains a high number of globally threatened grassland birds and is increasingly managed for livestock, with annual burning in remaining natural grasslands. The Strange-tailed Tyrant Alectrurus risora, a globally threatened grassland specialist, has suffered a $90 \%$ contraction in its original range. From 1996 to 2008 we monitored a breeding population in Formosa, north-east Argentina, and explored the effect on breeding of four accidental and one prescribed fires. The plant most frequently used for nesting was Imperata brasiliensis, but the frequency of use was lower after a fire than before. In years with a fire, the height of the plant used for nesting and the height of the nest were lower than in those without a fire. Females avoided nesting in the burned plot in the breeding season immediately after the prescribed fire, but they started to return to the burned plot by the second breeding season and did not discriminate between plots by the third breeding season after the fire. Movements of females after the prescribed fire did not affect nest survival, clutch size, hatchability or chick survival indicating this species was adapted to regular fires. However, our results also show that annual burning in the grassland negatively affects the settlement for reproduction of Strange-tailed Tyrants and that the intervals between burns in the same grassland should be longer than two years.

\section{Resumen}

Los pastizales del noreste de Argentina presentan un alto número de aves de pastizales globalmente amenazadas y en los últimos años está aumentando la actividad ganadera con quemas anuales. El Yetapá de Collar Alectrurus risora, un ave globalmente amenazada y especialista de pastizales, ha sufrido una disminución del $90 \%$ de su distribución original. Desde 1996 hasta 2008 monitoreamos una población reproductiva en Formosa, noreste de Argentina, y estudiamos el efecto de cuatro fuegos accidentales y uno prescripto sobre la nidificación. La planta usada con mayor frecuencia para nidificar fue Imperata brasiliensis, pero la frecuencia de uso fue menor después de los incendios. En años con fuego, la altura de la planta utilizada para nidificar y la altura del nido fue más baja que en años sin fuego. Las hembras evitaron nidificar en el área quemada durante la temporada reproductiva inmediatamente después del fuego prescripto, pero comenzaron a volver a dicha área durante la segunda temporada reproductiva, pero ya no discriminaron las parcelas quemada y no quemada durante la tercera temporada reproductiva después del fuego prescripto. Los movimientos entre parcelas de las hembras después del fuego prescripto no afectaron la supervivencia de nidos, el tamaño de postura, el éxito de eclosión o la supervivencia de pichones, indicando que esta especie estaría adaptada a fuegos regulares en los pastizales. Sin embargo, nuestros resultados también muestra que la quema anual de pastizales tiene un efecto negativo en el establecimiento de grupos reproductivos del Yetapá 
de Collar y que los intervalos entre quemas de un mismo pastizal deberían ser mayores a los dos años.

\section{Introduction}

Grassland birds are declining in South America (Vickery et al. 1999), North America (Askins et al. 2007), Europe (Donald et al. 2001) and other parts of the world (Butchart et al. 2004). The occurrence of threatened grassland birds is highly influenced by agricultural land-use (Murphy 2003, Donald et al. 2006) and main current causes of their decline are intensification of agricultural practices, habitat fragmentation, use of pesticides and increase in exotic and woody vegetation (BirdLife International 2008). Intensification of traditional rangeland management (i.e. annual burning and intensive grazing) has contributed in some cases to this decline, as it promotes habitat uniformity instead of heterogeneity (Fuhlendorf et al. 2006).

During the last 20 years, the remaining natural grasslands of north-east of Argentina have been increasingly managed for livestock grazing as a result of the spread of cultivated areas for soybean (Oesterheld 2008). Typical rangeland management techniques include cross-fencing, water management, use of herbicides and annual burning (Gibson 2009). Although fire was a natural disturbance in the north-east of Argentina, its frequency was lower (one fire every four years; Kunst and Bravo 2003). At present, annual burning is widespread in this region because it has a low cost, eliminates woody vegetation that tends to invade the grassland when fires are suppressed, and allows the rapid growth of fresh grasses (Morello and Adamoli 1974, Kunst and Bravo 2003). A study of fire patterns in South America shows that they occur in all the remaining natural grasslands of north-east Argentina and that most of them occur during late winter and spring (Di Bella et al. 2006). These changes will have caused the decline in many species of birds that inhabit grasslands and the north-east of Argentina holds a high number of globally threatened grassland species, such as Strange-tailed Tyrant Alectrurus risora, Sharp-tailed Tyrant Culicivora caudacuta, Saffroncowled Blackbird Xanthopsar flavus, Black-and-white Monjita Heteroxolmis dominicana and several species of Sporophila seedeaters (BirdLife International 2009).

Direct effects of fire on birds include destruction of nests, while indirect effects involve changes in vegetation which may favour some bird species over others. Although there are a large number of obligate grassland birds in the Neotropics (Vickery et al. 1999) and several of them are threatened (BirdLife International 2009), very few studies have analysed how they respond to fire. These studies have mainly focused on how fires modify the composition of bird communities, e.g. cerrado (Cavalcanti and Alves 1997, Parker and Willis 1997), Amazonian savanna (Cintra and Sanaiotti 2005), and southern pampas (Comparatore et al. 1996, Isacch et al. 2004). One recent exception is an experimental study by Petry and Krüger (2010) in highlands of southern Brazil which found that the Saffron-cowled Blackbird avoided habitats with tall grasses and bushes and forage more frequently in burned than unburned areas, suggesting that fire could be beneficial for this species. However, none of these studies have analysed in detail how burning affects the reproductive success of grassland birds and how individual birds respond to fire.

The Strange-tailed Tyrant Alectrurus risora is a tyrannine flycatcher that inhabits savannas and wet grasslands in the south of Paraguay and north-east of Argentina (Ridgely and Tudor 1994, Di Giacomo and Di Giacomo 2004; Figure 1a). It is an obligate grassland bird that depends exclusively on this habitat for nesting and feeding (Vickery et al. 1999, Fitzpatrick 2004). During the last century, it suffered a $90 \%$ contraction in its original range in association with conversion of natural grasslands to agriculture (Di Giacomo and Di Giacomo 2004). At present, it has the IUCN Red List category 'Vulnerable' and further declines in range and number are expected because suitable habitat is subject to current extensive agricultural intensification and afforestation (Collar et al. 1992, BirdLife International 2009). The current extent of occurrence of the Strange-tailed Tyrant in Argentina mainly includes private lands where fire is used as a management tool. Moreover, the breeding season of the species starts in early September (Di Giacomo and Di Giacomo 2004, Di Giacomo 2010), a time of year when fires are frequent in 


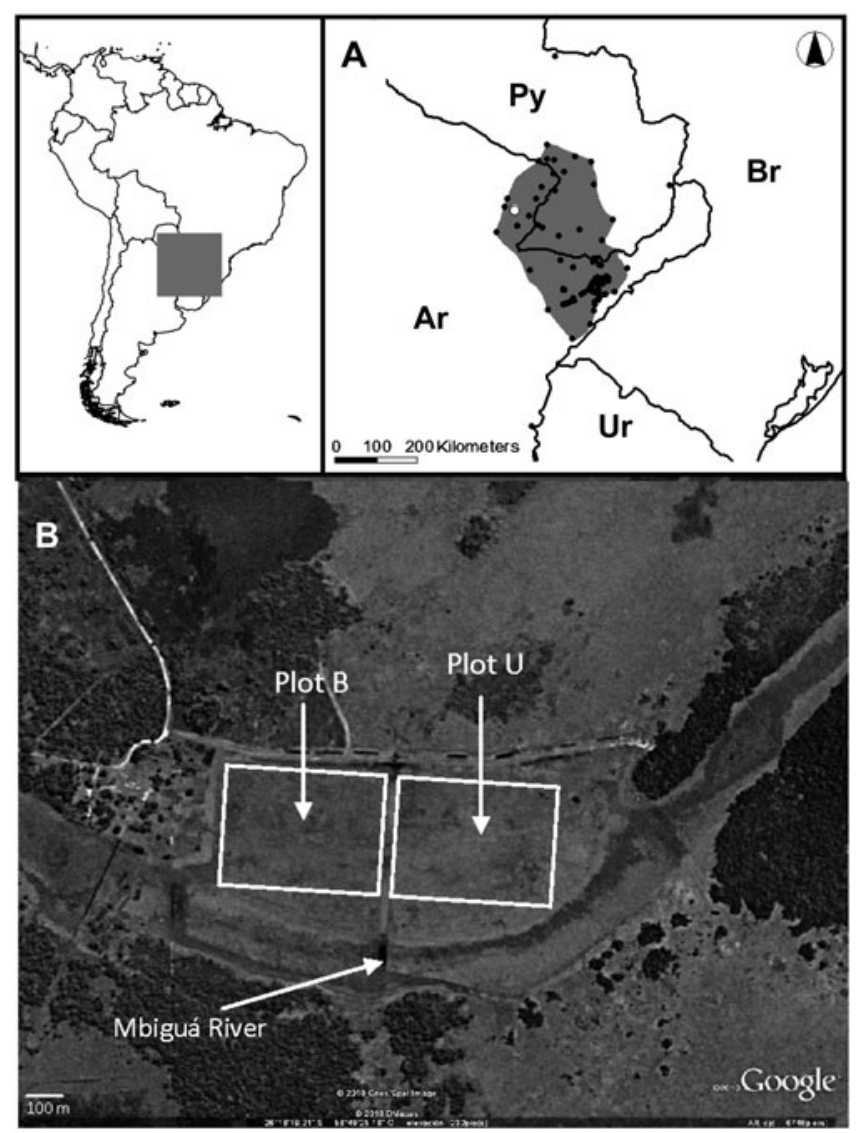

Figure 1. (a) Map showing the location of 'Reserva El Bagual' (white dot) and the present distribution of Strange-tailed Tyrants (grey area). The distribution of Strange-tailed Tyrants was plotted as the minimum convex polygon that covers all recent records for this species (black dots) obtained from Di Giacomo and Di Giacomo (2004) and Guyra Paraguay (2005). (b) Satellite image of our study area (Source: ( 2010 Google Earth, (O2010 Cnes/Spot Image, (O2010 DMapas). The white rectangles indicate the plots that we monitored during the Strange-tailed Tyrant's breeding seasons 1996/1997 to 2008/2009. Plot B corresponds to an area of $300 \times 500 \mathrm{~m}$ that was burned with a prescribed fire in August 2006. Plot U corresponds to an unburned control area of the same size. A firebreak (clear area) divides the two plots. There are other firebreaks around our study area to protect the breeding population of Strange-tailed Tyrants.

its present range. Therefore, the effects of grassland burning on reproductive success need to be understood to identify the most appropriate conservation measures for the species.

In this paper, we describe the response to fire of a breeding population of Strange-tailed Tyrant in the province of Formosa, north-east Argentina, that was monitored from September 1996 to January 2009. First, we explored the effects of fire on number of nesting attempts and their outcomes through a retrospective study of four accidental fires. In addition, we made a prospective study after one experimental prescribed burning of $50 \%$ of our study plot and recorded the distribution of banded males and females and the number of nesting attempts and their outcomes in the unburned and burned plots from two years before to two years after the experimental prescribed fire. 


\section{Methods}

\section{Study area}

We conducted our study at 'Reserva El Bagual' (hereafter REB), in the province of Formosa, Argentina $\left(26^{\circ} 18^{\prime} 23^{\prime} \mathrm{S}, 58^{\circ} 49^{\prime} 25^{\prime} \mathrm{W}\right.$, Figure 1a). REB is a 3,300 ha private protected area where livestock grazing and agriculture have been excluded since 1985 (Di Giacomo 2005a). The main habitat of REB is an open savanna of humid chaco (Cabrera and Willink 1980). Pyrogenic grasses such as Brazilian satintail Imperata brasiliensis and Andropogon lateralis dominate the grassland in well-drained terrains, while Paspalum spp. dominate in wet lowlands. At present, grazing within the reserve is done by a small population of Marsh Deer Blastocerus dichotomus (IUCN status 'Vulnerable'). REB is an Important Bird Area (IBA) that supports a diverse avifauna of 336 species, including populations of 13 species of conservation concern, such as breeding populations of Strange-tailed Tyrant and Sharp-tailed Tyrant (Di Giacomo 2005b).

\section{Study species}

Strange-tailed Tyrants have a polygynous mating system, with males holding close territories of 2-3 ha with two females on average (Di Giacomo 2010). Females nest from mid-September to mid-January and have on average two nesting attempts per breeding season (range 1-4; Di Giacomo 2010). Nests are built near the ground at the base or among the leaves of tall grasses (see Results). Nesting success is 0.23 on average, modal clutch size is three eggs and successful nests fledge on average two chicks. Parental care is provided exclusively by the female, who builds the nest, incubates the eggs and broods and feeds the chicks (Di Giacomo 2010).

\section{Data collection and analysis}

We collected data since 1996 in a grassland area of 50 ha located on the border of a small stream (Figure $1 \mathrm{~b}$ ) where 5-10 males and 10-20 females have nested regularly since 1995. This grassland is dominated by the tall grass (0.8-1.2 $\mathrm{m}$ in height) Imperata brasiliensis (Andropogoneae). Between 1996 and 2008 we recorded 292 nesting attempts (i.e. nests with laying) and for 286 of them we recorded the apparent nesting success (i.e. proportion of successful nests). In 283 of these nests we recorded the species of the plant in which the nest was built, in 261 the height of the plant, and in 265 the height of the nest (distance from ground to top of nest).

In 2004, in a 30 ha plot within our study area, we put poles ( $2 \mathrm{~m}$ in height) every $100 \mathrm{~m}$ forming a grid of 30 squares of $100 \times 100 \mathrm{~m}(300 \times 1,000 \mathrm{~m}$, Figure $1 \mathrm{~b})$. We used this grid to delimit the territories of banded males and females using the territory mapping technique (Bibby et al. 1992). During 2004-2005 we captured males during the non-breeding season and females during the non-breeding and breeding seasons using mist-nets. We ringed 8 males and 17 females on the tarsus with a numbered aluminium ring and a unique combination of coloured plastic rings. From 2004 to 2008 we mapped all observed individuals in the grid every $7-14$ days during the entire breeding season (from early September to late January). We considered that a male had a territory when it was recorded during four weeks or more (Vickery et al. 1992). Within the grid we found nests by observing female nesting behaviour (Martin and Geupel 1993) or by flushing females during systematic nest searching. We visited nests every 2-3 days until the chicks fledged or the nest failed.

From two years before to two years after the experimental prescribed fire (2004-2008) we estimated the main reproductive parameters (clutch size, hatching success, chick survival and nest survival) of nests in B and U plots $(n=146)$. We considered that the clutch was completed when the number of eggs remained constant for at least two consecutive days. We determined hatching success as the number of hatchlings divided by the number of eggs present in the nest at the time of hatching, and chick survival as the number of fledglings divided by the number of hatchlings. 
We estimated nesting success using the daily survival rate (DSR) estimator provided by program MARK (White and Burnham 1999). From the original data set we excluded 11 nests that had insufficient data for nest survival analysis. We considered that a nest was successful if it fledged chicks, depredated if all the eggs or chicks disappeared between two consecutive visits and deserted if the eggs were cold to the touch for two consecutive visits and the female did not attend the nest.

\section{Fire history at REB}

From 1996 to 2009 there were five fire events at REB. Three fires were initiated on neighbouring ranches dedicated to livestock grazing (October 8-13 1997; September 23-25 1999; and April 1-5 2003 ) and one within the reserve by illegal hunters (March 14-16 2001). Fires in 1997, 2001 and 2003 were of medium intensity and afterwards there remained small patches of unburned grasses. However, in 1999 there was a fire of high intensity that totally eliminated the vegetation cover. In 2004, the managers of REB started a programme of fire management to protect the habitat of the breeding populations of Strange-tailed Tyrants and Sharp-tailed Tyrants. The programme included the construction of a firebreak system and the use of prescribed fires to control the biomass of grasses and to prevent the invasion of woody vegetation (Morello and Adamoli 1974). One of the firebreaks divided our study plot into two plots of 15 ha (Figure 1b). In August 2006 one of these plots was burned under controlled conditions (Marino 2007). We used this experimentally burned plot and the unburned plot to study how fire affected the distribution of Strange-tailed Tyrants and their reproductive parameters.

\section{Statistical analysis}

For most analyses we used nonparametric statistics due to lack of normality of the data and relatively small sample size (Siegel and Castellan 1988). We used Mann-Whitney U tests to compare the height of plants and nests between the years with and without fires. We used Kruskal-Wallis tests to compare reproductive parameters in the unburned plot between the years before the prescribed fire, the year of the prescribed fire and the years after the prescribed fire. We used a binomial test to examine if the distribution of males, females and nests between unburned and burned plots occurred with equal probabilities. We estimated specific daily survival rates with software MARK (White and Burnham 1999) and we used the program CONTRAST to examine differences in daily survival rates (Hines and Sauer 1989). All values reported are means \pm SE.

\section{Results}

\section{Nesting attempts in years with and without fires}

Figure 2 shows the number of nesting attempts per year in the 30 ha study plot and the time when fires occurred. Fires differed in origin, time of the year at which they occurred, size and intensity. These differences were probably the cause of the high variation in number of nesting attempts in years with a fire (range 2-30). The most noticeable effect of fire on the number of nesting attempts occurred in 1999. This year the fire occurred at the beginning of the spring (23-25 September) after an extremely dry winter. The fire eliminated the vegetation cover in almost all the study area. That year there were two nesting attempts only, and both occurred at the end of the breeding season (12 December and 5 January) in two small patches that had not been affected by the fire. In the other three accidental fires and in the prescribed fire, we did not observe a clear decrease in the number of nesting attempts, probably because the birds nested in the remaining patches of unburned grassland. As a result of this, we did not detect differences in the number of nesting attempts between years with and without a fire (with: $20.2 \pm 4.9, n=5$; without: 24.I \pm 3.2, $n=8$; Mann-Whitney $U$ test: $Z=-0.59, P=0.56)$. 


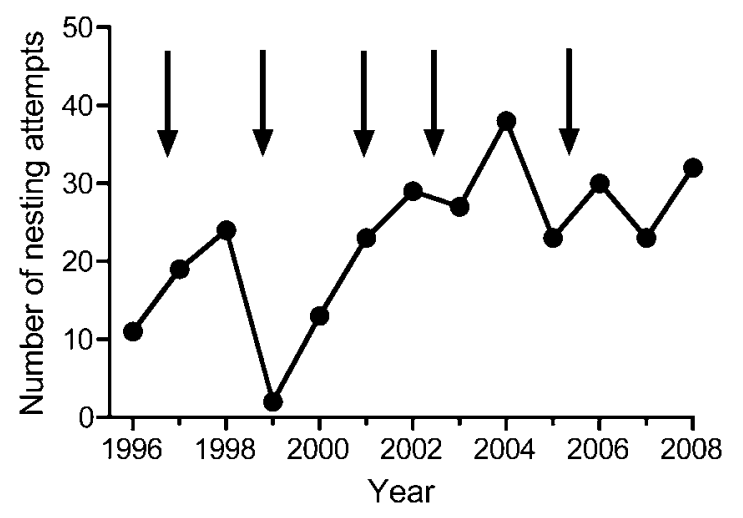

Figure 2. Number of Strange-tailed Tyrant nesting attempts per breeding season (from 1996/ 1997 to 2008/2009) at our study plot. Arrows indicate the fire events (spring 1997, spring 1999, summer 2001, autumn 2003 and winter 2006).

\section{Plant and nest heights in years with and without a fire}

Sixty-two percent of the nests $(175 / 283)$ were built in Imperata brasiliensis, the dominant grass species in our study area. Other species of grasses used for nesting were Paspalum spp. (23/283), Andropogon spp. (13/283), Eustachys distichophylla (12/283), Elionurus muticus (11/283) and Schizachyrium spicatum (10/283). The frequency of use of Imperata brasiliensis was lower in years with a fire than in those without a fire $\left(22 / 68\right.$ vs. $\left.153 / 215 ; \chi^{2}=31.3, P<0.0001\right)$.

The height of the plant used for nesting was lower in years with a fire than in those without a fire $(54.9 \pm 2.6 \mathrm{~cm}, n=60$ vs. $80.7 \pm 1.4 \mathrm{~cm}, n=201$; Mann-Whitney $U$ test, $Z=7.4, P<$ 0.0001 ; Figure $3 \mathrm{a})$. Similarly, in years with a fire the nests were built at a lower height than in years without a fire $(6.0 \pm 2.6 \mathrm{~cm}, n=59$ vs. $40.0 \pm 1.4 \mathrm{~cm}, n=203$; Mann-Whitney $U$ test, $Z=8.9, P<0.0001$ ), with nearly $80 \%$ of the nests built directly on the ground (Figure $3 b$ ). We did not detect differences in apparent nest survival between years with a fire and without a fire (with fire: $18 / 68$; without fire 62/156; Contingency test $\chi^{2}=0.03, P=0.87$ ).

\section{Distribution of males, females and nests before and after the prescribed fire}

During the breeding seasons 2004 and 2005 (before the prescribed fire) there were seven and eight males and 17 and 16 females, respectively. The number of nesting attempts during these breeding seasons was 38 (2004) and 23 (2005) (Figure 4). The settlement of males and females and the number of nesting attempts in plots $\mathrm{B}$ and $\mathrm{U}$ did not differ from random (binomial tests, $P>0.13$ for all comparisons, Figure 4). During the 2006 breeding season (year of the prescribed fire) all males and females settled in the unburned plot and all nesting attempts occurred in that plot (Binomial tests, $P=0.03$ for males, $P<0.001$ for females and $P<0.001$ for nesting attempts, Figure 4$)$. In 2006, the number of males in the unburned plot was double the number observed in the same plot during the previous breeding seasons. Moreover, it held three ringed females that had nested in the burned plot the previous breeding season. The other five ringed females that nested in the unburned plot had nested there the previous season. During the breeding season 2007 (one year after the prescribed fire) there were two males, three females and six nesting attempts in burned plot, while in the unburned plot there were three males, eight females and 17 nesting attempts (Binomial tests, $P=0.50$ for males, $P=0.11$ for females and $P=0.02$ for nesting attempts). During this breeding season, one banded female that had switched from the burned to the unburned plot during the breeding season 2006 returned to the burned plot. Finally, during the breeding season 2008 the 


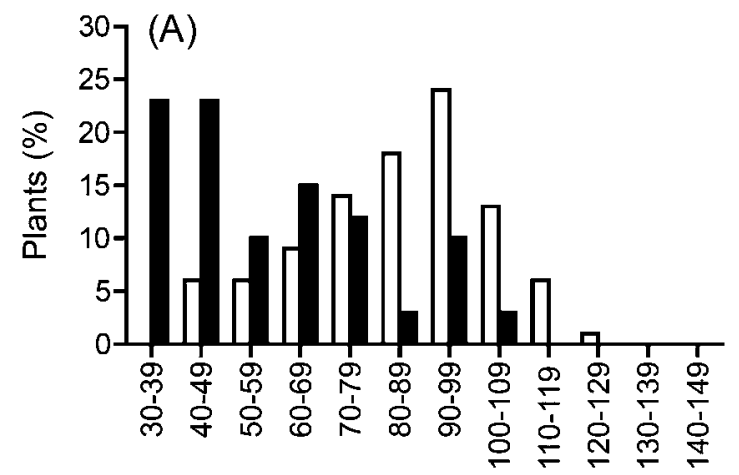

Plant height $(\mathrm{cm})$

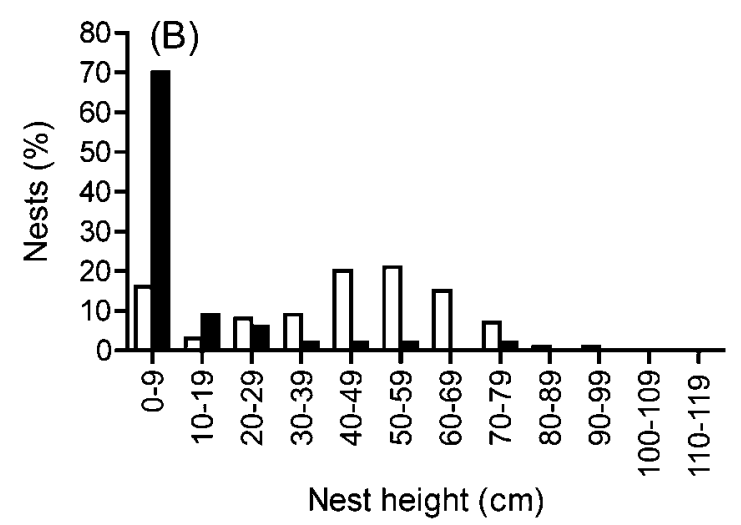

Figure 3. Frequency distributions of the heights of plants with nests (A) and height of nests (B) of Strange-tailed Tyrant built in years without a fire (white bars, $n=201$ plants, $n=205$ nests) or with a fire (black bars, $n=60$ plants and nests). Data correspond to nesting attempts that occurred during the breeding seasons 1996/1997 to 2008/2009.

number of females and nesting attempts in the burned plot increased from 3 to 8 and from 6 to 14, respectively (Binomial tests, $P>0.30$ for all comparisons, Figure 4 ).

\section{Reproductive parameters and nesting success before and after the prescribed fire}

Daily survival rate in the unburned plot the year of the prescribed fire did not differ from that of years before the fire $\left(\chi^{2}=0.15, P=0.70\right.$, Table 1$)$. However, DSR in the unburned plot after the prescribed fire was higher than that of the year with fire $\left(\chi^{2}=5.76, P=0.016\right)$, or the years before fire $\left(\chi^{2}=6.73, P=0.01\right)$. Daily survival rates in the burned plot did not differ between years before and after the prescribed fire (2004-2005: 0.960 \pm 0.010; 2007-2008: 0.964 \pm 0.009; $\chi^{2}=0.09, P=0.77$, table 1 ).

Clutch size, hatching success and chick survival in nests built in the unburned plot did not differ between the years before the prescribed fire, the year with the fire and those after the fire (Kruskall-Wallis test, $H_{2}=2.87, P=0.24$ for clutch size; $H_{2}=3.18, P=0.20$ for hatching success; and $H_{2}=0.63, P=0.73$ for chick survival). As a result, there were no differences in the number of young fledged per nest between the years before the fire (2004-2005: 2.29 $\pm 0.33, n=7)$, the year with the fire (2006: $2.00 \pm 0.35, n=6$ ) and those after the fire (2007-2008: $2.21 \pm 0.23, n=14$, Table 1). 

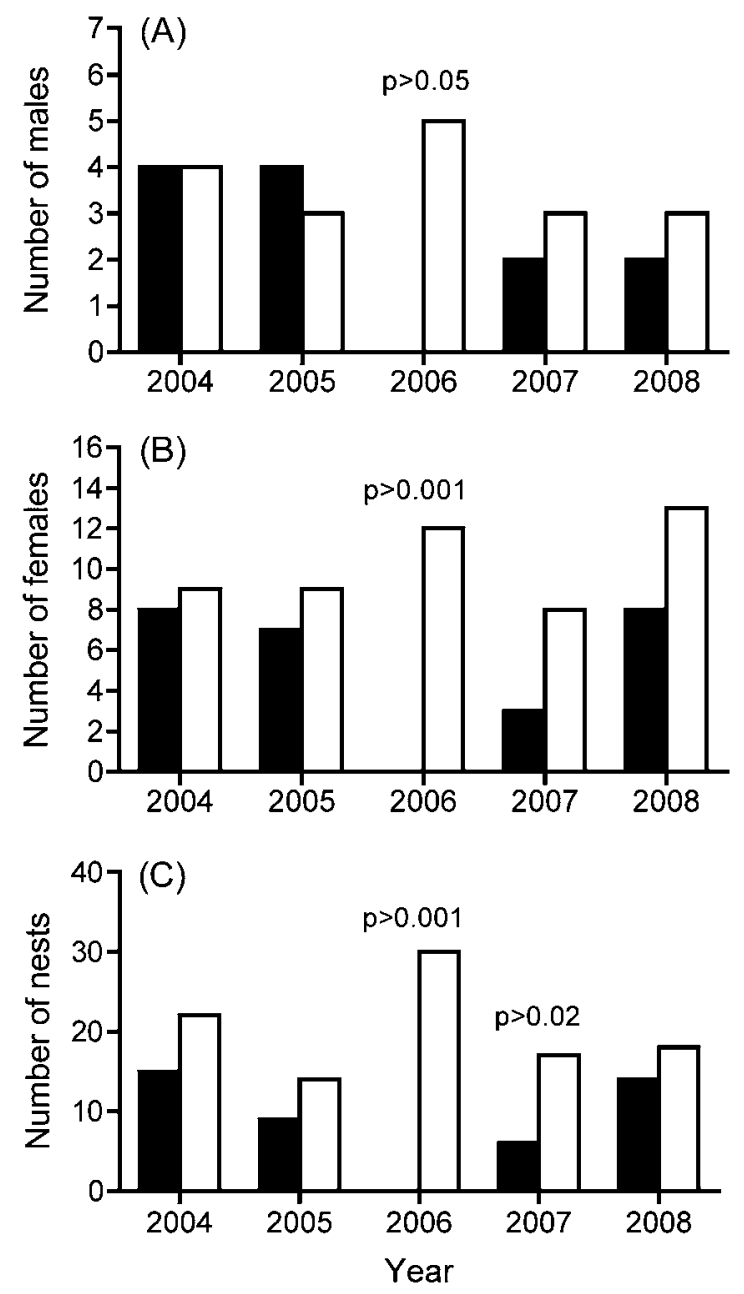

Figure 4. Number of Strange-tailed Tyrant territorial males (A) and females (B), and number of nesting attempts (C) in our study area during the breeding seasons 2004-2008. Black bars indicate numbers in the plot that was burned with the prescribed fire in August 2006 while white bars indicate numbers in the unburned control plot.

\section{Discussion}

Our results show that grassland burning affected the reproductive behaviour of Strange-tailed Tyrants. In years with a fire, the height of the plant used for nesting and the height of the nest was lower than in those without a fire, but this was not associated with changes in apparent nest survival. Data on female distribution before and after the prescribed fire show that all females avoided nesting in the burned plot in the breeding season immediately after the fire. Females started to return to this plot in the second breeding season after the fire and by the third breeding season they did not discriminate between burned and unburned plots. Consistent with this observation, Albute (2009) reported that one year after the fire, above-ground biomass was significantly lower in the burned than in the unburned plot, but after two years it did not differ between plots. The higher density of nests in the unburned plot in the year of the prescribed fire 
Table 1. Main reproductive parameters of Strange-tailed Tyrant Alectrurus risora nesting in the unburned plot before the prescribed fire (2004 and 2005), the year of the fire (2006) and the years after the fire (2007 and 2008). Values indicate mean \pm standard error. The number between parentheses indicates number of nests for each period. For details of how each parameter was calculated see methods.

\begin{tabular}{lllll}
\hline Years & Daily survival rate & Clutch size & Hatching success & Chick survival \\
\hline $2004-2005$ & $0.949 \pm 0.010(34)$ & $2.53 \pm 0.11(32)$ & $0.89 \pm 0.04(22)$ & $0.90 \pm 0.09(7)$ \\
2006 & $0.949 \pm 0.011(26)$ & $2.79 \pm 0.13(24)$ & $0.79 \pm 0.05(16)$ & $0.81 \pm 0.10(6)$ \\
$2007-2008$ & $0.978 \pm 0.005(32)$ & $2.79 \pm 0.12(29)$ & $0.92 \pm 0.04(25)$ & $0.89 \pm 0.07(14)$ \\
\hline
\end{tabular}

did not affect the main reproductive parameters of Strange-tailed Tyrants, as there were no differences in nest survival, clutch size, hatching success and chick survival between that year and the years before and after the fire. In addition, nest survival in the burned plot in the years after the fire did not differ from that in the years before the fire.

Fire could be a useful tool for managing the habitat of obligate Neotropical grassland birds such as Strange-tailed Tyrants because it allows the maintenance of grasses by preventing the increase of woody cover (Morello and Adamoli 1974). Bush encroachment has been proposed as an important threat for the Sidamo Lark Heteromirafra sidamoensis, a 'Critically Endangered' grassland endemic in southern Ethiopia, and reversing fire suppression policies appears necessary to avoid the extinction of this species (Spottiswoode et al. 2009). Likewise, based on a population viability analysis Duca et al. (2009) recommended the use of fire management in small reserves in cerrado savannas for conserving a 'Near Threatened' endemic, the White-banded Tanager Neothraupis fasciata.

Prescribed fire could be a management tool for maintaining suitable habitat for Strange-tailed Tyrants in pyrogenic grasslands (i.e. to avoid bush encroachment) and for reducing the risk of large accidental fires (like that of 1999), which can suppress breeding and threaten the population. Our results indicate that the impact of prescribed fires on the reproduction of Strange-tailed Tyrant could be minimised by choosing the appropriate season at which the grassland is burnt (autumn or early winter), the size and intensity of the fire, and its frequency. In years when accidental fires did not affect the whole area (1997, 2001 and 2003) the birds nested in the remaining unburned patches and the number of nesting attempts was similar to years without fire; and although in these years Strange-tailed Tyrants nested in lower plants and at a lower height, this was not associated with a lower nesting success.

As regards the frequency of fires, we observed that the third breeding season after the prescribed fire the birds did not show avoidance of the burned patch, suggesting that it had by then become as attractive as the unburned one. Similarly, Petry and Krüger (2010) commented that Saffron-cowled Blackbirds returned to a burned marshland to breed only when the plants were developed enough and the marshland structure was recovered, which occurred three breeding seasons after the fire. These results suggest that the intervals between burns should be longer than two years. However, our study cannot provide an indication of how long the interval should be, as we did not have long periods without fire. The burning of small fragments of grasslands would allow a mosaic of unburned nearby patches to be maintained as refuges, thus facilitating the colonisation of burned patches once the vegetation recovers. In addition, some authors have reported that the availability of herbivorous arthropods increases in recently burned patches (Warren et al. 1987, Swengel 2001, Shochat et al. 2005), which could provide Strange-tailed Tyrants additional food, although this requires further investigation.

On the contrary, burning of the grassland every year, the common practice for livestock grazing in the region (Kunst and Bravo 2003, Di Bella et al. 2006), has a negative impact on Strange-tailed Tyrant settlement for reproduction. The same effect was observed in other grassland birds where the frequency of fires notably affects the abundance of grass-dependent species, which are least abundant or absent at sites in the breeding season immediately following burning (Powell 2006). For example in USA, Henslow's Sparrow Ammodramus henslowii, a grassland obligate of 
conservation concern, is completely absent from pastures that are annually burned (Coppedge et al. 2008). Similarly, in Australia, detrimental fire regimes contributed to the extinction of two of the three bird species and three of the four bird subspecies which have disappeared since European colonisation (Woinarski and Recher 1997).

In north-east Argentina there are 16 Important Bird Areas (IBAs) that include populations of Strange-tailed Tyrants (Di Giacomo 2005b). These IBAs comprise approximately 1 million ha of wet grasslands and savannas. Only six of these 16 IBAs (covering 150,000 ha) are managed to some extent as protected areas with the exclusion of livestock and under some type of fire management. The remaining IBAs are private land dedicated to livestock grazing where the commonest management practice is annual burning. Under this scenario, it would be expected that Strange-tailed Tyrants and other threatened species that require tall grass habitat for breeding have experienced reductions in their populations or local extinctions. Such species of birds are now at increasing risk of extinction because of intensifying livestock management in response to spreading soybean cultivation (Oesterheld 2008). If we want to conserve viable populations of Strange-tailed Tyrants, we urgently need to influence the current use of fire on private lands dedicated to livestock grazing where this species is still present.

\section{Acknowledgements}

We thank Alparamis SA and Aves Argentinas for allowing us to conduct this study at 'Reserva El Bagual' and Dr. Gustavo Marino for helpful comments on the ecology of subtropical grasslands. ASDG was supported by a Canon National Park Science Scholarship and a Doctoral Scholarship of the University of Buenos Aires. JCR is Research Fellow of the Consejo Nacional de Investigaciones Científicas y Técnicas de Argentina.

\section{References}

Albute, V. C. (2009) Evaluación de la productividad primaria neta aérea de un pastizal de Elionurus muticus e Imperata brasiliensis de la Reserva El Bagual (Provincia de Formosa: Argentina) a partir de una quema prescripta. Facultad de Humanidades y Ciencias, Universidad Nacional del Litoral. Tesis de Licenciatura en Biodiversidad.

Askins, R. A., Chávez-Ramírez, F., Dale, B. C., Haas, C. A., Herkert, J. R., Knopf, F. and Vickery, P. D. (2007) Conservation of grassland birds in North America: understanding ecological processes in different regions. Ornithol. Monogr. 64: 1-46.

Bibby, C. J., Burgess, N. D. and Hill, D. A. (1992) Bird census techniques. London, UK: Academic Press.

BirdLife International (2008) State of the world's birds: indicators for our changing world. Cambridge, UK: Birdlife International.

BirdLife International (2009) Threatened birds of the world. Species factsheets. Downloaded from http://www.birdlife.org on $10 / 12 / 2009$.
Butchart, S. H. M., Stattersfield, A. J., Bennun, L. A., Shutes, S. M., Akçakaya, H. R., Baillie, J. E. M., Stuart, S. N., Hilton-Taylor, C. and Mace, G. M. (2004) Measuring global trends in the status of biodiversity: red list indices for birds. PLoS Biol. 2: 2294-2304.

Cabrera, A. L. and Willink, A. (1980) Biogeografía de América Latina. Washington DC: Organización de Estados Americanos.

Cavalcanti, R. B. and Alves, M. A. S. (1997) Effects of fire on savanna birds in central Brazil. Ornitol. Neotrop. 8: 85-87.

Cintra, R. and Sanaiotti, T. M. (2005) Fire effects on the composition of a bird community in an Amazonian savanna (Brazil). Braz. J. Biol. 65: 683-695.

Collar, N. J., Gonzaga, L. P., Krabbe, N., Madroño Nieto, A., Naranjo, L. G., Parker, III, T. A. and Wege, D. C. (1992) Threatened birds of the Americas. The ICBP/ IUCN Red Data Book. Cambridge, UK: International Council for Bird Preservation.

Comparatore, V. M., Martínez, M. M., Vassallo, A. L., Barg, M. and Isacch, J. P. 
(1996) Abundancia y relaciones con el hábitat de aves y mamíferos en pastizales de Paspalum quadrifarium (Paja Colorada) manejados con fuego (Prov. de Buenos Aires, Argentina). Interciencia 21: 228-237.

Coppedge, B. R., Fuhlendorf, S. D., Harrell, W. C. and Engle, D. V. (2008) Avian community response to vegetation and structural features in grasslands managed with fire and grazing. Biol. Conserv. 141: 1196-1203.

Di Bella, C. M., Jobbágy, E. G., Paruelo, J. M. and Pinnock, S. (2006) Continental fire density in South America. Global Ecol. Biogeogr. 15: 192-199.

Di Giacomo, A. G. (2005a) Aves de la Reserva El Bagual. Pp. $201-465$ in A. G. Di Giacomo and S. F. Krapovickas, eds. Historia natural y paisaje de la Reserva El Bagual, Provincia de Formosa, Argentina. Inventario de la fauna de vertebrados y de la flora vascular de un área protegida del Chaco Húmedo. Temas de Naturaleza y Conservación 4. Buenos Aires: Aves Argentinas/Asociación Ornitológica del Plata.

Di Giacomo, A. S. (2005b) Áreas importantes para la conservación de las aves en Argentina. Sitios prioritarios para la conservación de la biodiversidad. Temas de Naturaleza y Conservación 5. Buenos Aires: Aves Argentinas/Asociación Ornitológica del Plata.

Di Giacomo, A. S. (2010) Ecología y conservación del Yetapá de collar (Alectrurus risora, tyrannidae). Unpubl. Ph.D. thesis, Universidad de Buenos Aires.

Di Giacomo, A. S. and Di Giacomo, A. G. (2004) Extinción, historia natural y conservación de las poblaciones del Yetapá de Collar (Alectrurus risora) en la Argentina. Ornitol. Neotrop. 15: 145-157.

Donald, P. F., Green, R. E. and Heath, M. F. (2001) Agricultural intensification and the collapse of Europe's farmland bird populations. Proc. R. Soc. Lond. B. 268: 25-29.

Donald, P. F., Sanderson, F. J., Burfield, I. J. and van Bommel, F. P. J. (2006) Further evidence of continent-wide impacts of agricultural intensification on European farmland birds, 1990-2000. Agr. Ecosys. Environ. 116: 189-196.

Duca, C., Yokomizo, H., Marini, M. A., and Possingham, H. P. (2009) Cost-efficient conservation for the White-banded tanager (Neothraupis fasciata) in the Cerrado, central Brazil. Biol. Conserv. 142: 563-574.

Fitzpatrick, J. W. (2004) Family Tyrannidae (Tyrant-flycatchers). Pp. $170-462$ in J. del Hoyo, A. Elliot and D. A. Christie, eds. Handbook of the birds of the world. Vol. 9. Cotingas to pipits and wagtails. Barcelona: Lynx Edicions.

Fuhlendorf, S. D., Harrell, W. C. Engle, D. M. Hamilton, R. G. Davis, C. A. and Leslie, Jr. D. M. (2006) Should heterogeneity be the basis for conservation? Grassland bird response to fire and grazing. Ecol. Appl. 16: 1706-1716.

Gibson, D. J. (2009) Grasses and grassland ecology. New York: Oxford University Press.

Guyra Paraguay (2005) Atlas de las aves de Paraguay. Asunción: Asociación Guyra Paraguay.

Hines, J. E.and Sauer, J. R. 1989. Program CONTRAST - A general program for the analysis of several survival or recovery rate estimates. Washington, DC: US Fish \& Wildlife Service (Fish \& Wildlife Technical Report 24).

Isacch, J. P., Holz, S., Ricci, L. and Martínez, M. M. (2004) Post-fire vegetation change and bird use of a salt marsh in coastal Argentina. Wetlands 24: 235-243.

Kunst, C. R. and Bravo, S. (2003) Ecología y regimen de fuego en la región chaqueña argentina. Pp. 109-118 in C. R. Kunst, S. Bravo and J. L. Panigatti, eds. Fuego en los ecosistemas argentinos. Santiago del Estero, Argentina: Ediciones INTA.

Marino, G. D. (2007) Primer avance en el estudio de la ecología y manejo del fuego en los pastizales de la Reserva El Bagual (Formosa, Argentina). Unpubl. report. Santa Fe: Universidad Nacional del Litoral and Aves Argentinas.

Martin, T. E. and Geupel, G. R. (1993) Nestmonitoring plots: Methods for locating nests and monitoring success. J. Field Ornithol. 64: 507-519.

Morello, J. and Adamoli, J. (1974) Las grandes unidades de vegetación y ambiente del Chaco Argentino. Segunda parte: Vegetación y ambiente de la provincia de Chaco. Buenos Aires: Instituto Nacional de 
Tecnología Agropecuaria. Serie Fitogeográfica $\mathrm{N}^{\circ}$ 8: 1-130.

Murphy, M. T. (2003) Avian population trends within the evolving agricultural landscape of the eastern and central United States. Auk 120: 20-34.

Oesterheld, M. (2008) Impacto de la agricultura sobre los ecosistemas: fundamentos ecológicos y problemas más relevantes. Ecol. Aust. 18: 337-346.

Parker, III, T. A. and Willis, E. O. (1997) Notes on three tiny grassland flycatchers, with comments on the disappearance of South American fire-diversified savannas. Ornithol. Monogr. 48: 549-556.

Petry, M. V. and Krüger, L. (2010) Frequent use of burned grasslands by the vulnerable Saffron-cowled Blackbird Xanthopsar flavus: implications for the conservation of the species. J. Ornithol. 151: 599-605.

Powell, A. F. L. A. (2006) Effects of prescribed burns and bison (Bos Bison) grazing on breeding bird abundances in tallgrass prairie. Auk 123: 183-197.

Ridgely, R. S. and Tudor, G. (1994) The birds of South America. Volume 2: The suboscine passerines. Austin, USA: University of Texas Press.

Shochat, E., Wolfe, D. H., Patten, M. A., Reinking, D. L. and Sherrod, S. K. (2005) Tallgrass prairie management and bird nest success along roadsides. Biol. Conserv. 121: 399-407.
Siegel, S. and Castellan, N. J. (1988) Nonparametric statistics for the behavioural sciences. New York: McGraw-Hill.

Spottiswoode, C. N., Wondafrash, M., Gabremichael, M. N., Dellelegn Abebe, Y., Mwangi, M. A. K., Collar, N. J. and Dolman, P. M. (2009) Rangeland degradation is poised to cause Africa's first recorded avian extinction. Anim. Conserv. 12: 249-257.

Swengel, A. B. (2001) A literature review of insect responses to fire, compared to other conservation managements of open habitat. Biodivers. Conserv. 10: 1141-1169

Vickery, P. D., Hunter, Jr. M. L. and Wells, J. V. (1992) Is density an indicator of breeding success? Auk 109: 706-710

Vickery, P. D., Tubaro, P. L., Cardoso da Silva, J. M., Peterjohn, B. G., Herkert, J. R. and Cavalcanti, R. B. (1999) Conservation of grassland birds in the Western Hemisphere. Stud. Avian Biol. 19: 2-26.

Warren, S. D., Scifres, C. J. and Teel, P. D. (1987) Response of grassland arthropods to burning: a review. Agric. Ecosyst. Environ. 19: 103-130.

White, G. C. and Burnham, K. P. (1999) Program MARK: Survival estimation from populations of marked animals. Bird Study 46: $120-138$.

Woinarski, J. C. Z. and Recher, H. F. (1997) Impact and response: A review of the effects of fire on the Australian avifauna. Pacific Conserv. Biol. 3: 183-205.

\title{
ALEJANDRO G. DI GIACOMO
}

Departamento de Conservación, Aves Argentinas/Asociación Ornitológica del Plata, Matheu 1246, C1249AAB Buenos Aires, Argentina.

\author{
ADRIAN S. DI GIACOMO*, JUAN C. REBOREDA \\ Departamento de Ecología, Genética y Evolución, Facultad de Ciencias Exactas y Naturales, \\ Universidad de Buenos Aires, Pabellón II Ciudad Universitaria, C1428EGA Buenos Aires, \\ Argentina.
}

${ }^{*}$ Author for correspondence; e-mail: digiacomo@ege.fcen.uba.ar

Received 4 May 2010; revision accepted 26 October 2010; Published online 11 February 2011 